\title{
ФОРМУВАННЯ ОРГАНІЗАЦІЙНО-УПРАВЛІНСЬКОГО МЕХАНІЗМУ ЗАБЕЗПЕЧЕННЯ НАУКОВО-ТЕХНІЧНОГО ТА ІННОВАЦИЙНОГО РОЗВИТКУ УКРАЇНИ НА ОСНОВІ ФУНКЦІОНАЛЬНОГО ПІДХОДУ
}

\begin{abstract}
Мета. Удосконалення організаційно-управлінського механізму забезпечення науково-технічного та інновачійного розвитку Украӥни на основі функціонального підходу.

Методика. Методологічною основою дослідження стали фундаментальні роботи зарубіжних і вітчизняних учених $i$ практиків з питань державного стратегічного управління на мікро-, макро- та регіональному рівнях. Обтрунтованість результатів дослідження, висновків і рекомендаиій в роботі доведено використанням методів системного, організаційного та економічного аналізу.

Результати. Запропоновано комплексний організаційно-управлінський механізм забезпечення науково-технічного та інновачійного розвитку Украӥни. Визначено основні структурні елементи механізму: суб'єкт управління, об'єкт управління, цілі управління, критерії управління, елементи об 'єкта управління, ресурси управління, методи управління. Наведено цілі та задачі механізму, рівні управління. Встановлено, що введення в дію запропонованого організачійно-управлінського механізму забезпечення науково-технічного та інноваційного розвитку України дозволить сформувати ефективну начіональну науково-технічну та інноваційну стратегію розвитку, що призведе до повного використання науково-технічного потенціалу країни, економії та більш раціонального використання всіх видів ресурсів.

Наукова новизна. Організаційно-управлінський механізм забезпечення науково-технічного та інноваційного розвитку України заснований на основі функиіонального підходу.

Практична значимість. Результати дослідження формують теоретико-методичні й організачійні засади для забезпечення сталого науково-технічного та інновачійного розвитку країни.
\end{abstract}

Ключові слова: стратегічне управління, науково-технічний та інноваційний розвиток, державний механізм управління, багаторівнева система управління

Вступ. Глобалізація світової економіки $є$ важливим фактором сучасних економічних відносин, який визначає розвиток світового господарства на межі XXI століття. Глобалізація і надалі впливатиме на торгівельні відносини, фінансові потоки, науково-технічний прогрес, глобальне навколишнє середовище, а тому вимагатиме пошуку динамічної рівноваги як на міжнародному так і на національному рівнях.

Структурні зрушення, що виникли в економічному середовищі країн $\epsilon$ наслідком процесу глобалізації, які спричиняють пошук механізму та важелів розбудови власної економічної політики щодо формування сучасного середовища 3 принципово новою господарчою системою, де головним виробничим ресурсом $\epsilon$ інформація й знання, а роль вирішального чинника виробництва інновація.

Глобалізаційні процеси вимагають від держави вирішення ряду завдань, що стосуються підтримки, мотивації та подальшого розвитку інтелектуального потенціалу нації, його ефективного використання для підвищення рівня конкурентоспроможності країни через застосування ефективного державного управління та використання дієвих національних стратегій розвитку.

Україна за економічними можливостями, інтелектуальним i науково-технічним потенціалом все ще належить до найбільших розвинутих європейських держав. Українське суспільство має й повинне використати свої можливості для того, щоб зайняти гідне місце на світовій арені, посісти провідні позиції серед держав 3 постіндустріальною економікою.

Таким чином, глобальний за змістом та інноваційний за характером розвиток світового економічного господарства i внутрішнього соціально-економічного середовища вимагає від України здійснення ефективного стратегічного управління науково-технічним та інноваційним розвитком держави в умовах глобальної конкуренції та вибору власної Стратегії науково-технічного розвитку країни.

Аналіз останніх досліджень i публікацій. Дослідженням проблематики державного стратегічного управління на мікро-, макро- та регіональному рівнях займалися наступні вчені: І. Ансофф [1], Г. Мінцберг, Б. Альстренд, Д. Лемпел [11], Т. Кун [9], Т. О’Шеннессі [14], І. Вільсон [16], Д. Шендел та 
Ч. Хуфер [15], В. Катькало [7]. Пізніші спроби систематизувати результати досліджень у сфері стратегічного управління знаходимо у [5;8].

Однак все ще залишаються не вирішеними проблеми стратегічного управління науково-технічним розвитком держави. Водночас, в Україні немає чіткої державної стратегії науково-технічного розвитку як головного чинника забезпечення переходу до інноваційної економіки.

Мета статті (постановка завдання).

Віддаючи належне внеску науковців у теорію та практику стратегічного управління науково-технічним розвитком країни, подальшого теоретичного i науковометодичного обгрунтування потребує питання, що пов'язане 3 удосконаленням механізмів реалізації стратегічного управління НТР за умов глобальної конкуренції. Отже, метою дослідження $\epsilon$ удосконалення організаційноуправлінського механізму забезпечення науково-технічного та інноваційного розвитку України за рахунок застосування принципів інноваційного управління.

Методи дослідження. Теоретичну базу дослідження становлять положення теорії стратегічного управління, теорії економічного розвитку, теорії інновацій, теорії державного управління, концепції глобальної економіки, теоретико-методологічні доробки сучасних економічних і управлінських наукових шкіл $\mathrm{i}$ окремих науковців.

В процесі дослідження застосовано системний підхід, структурний синтез (при удосконаленні організаційно-управлінського механізму забезпечення науково-технічного та інноваційного розвитку України), логічне узагальнення (для формування висновків).

\section{Виклад основного матеріалу.} Організаційно-управлінський механізм забезпечення науково-технічного та інноваційного розвитку України - це багаторівнева система управління, метою якої $\epsilon$ збалансування всіх складових розвитку (економічних, виробничих, інноваційних, науково-технічних, соціальних, інтелектуальних), практичне застосування якого потребує в сучасних умовах певної реформації. Даний механізм буде ефективний лише за умови узгодження стратегічних цілей різних рівнів господарювання, що визначаються та декларуються у стратегіях кожного $з$ них.
Основу механізмів формування та реалізації науково-технічної політики становлять: гнучкий економіко-правовий механізм, орієнтований на формування різноманітних організаційних форм і структур організації НДДКР та впровадження їхніх наслідків; широка кооперація ресурсів приватних, державних та університетських дослідницьких структур; конкурсний принцип надання ресурсів, виконання програм НДДКР та дійове стимулювання розробки і впровадження нововведень; стимулююча дія механізмів ринкової конкуренції та зацікавленості виробників до нововведень, розвиток науковотехнічного підприємництва; патентна політика та законодавство, спрямовані на стимулювання винахідницької та інноваційної діяльності; можливість визначення напрямів дослідницької діяльності та форм зв'язків із системою підготовки кадрів для академічних та університетських структур [4, с. 15].

Стратегічною метою державної науковотехнічної політики $\epsilon$ забезпечення інноваційного розвитку держави за рахунок динамічного та збалансованого регіонального розвитку, шляхом підвищення конкурентоздатності регіонів, активізації інноваційних процесів, розвитку та збереження інтелектуального капіталу нації, забезпечення державної охорони інтелектуальної власності та, як наслідок, підвищення рівня життя населення.

Прийнявши до уваги описані в роботах [23; 12-13] функції, методи, інструменти, важелі державного управління та чинники, що стримують науково-технічний та інноваційний розвиток країни, спираючись на міжнародний досвід та наведені в роботах $[4 ; 6 ; 10]$ напрями удосконалення механізмів державного управління, нами запропоновано комплексний організаційно-управлінський механізм забезпечення науково-технічного та інноваційного розвитку України (рис. 1).

Згідно запропонованого варіанту, організаційно-управлінський механізм забезпечення науково-технічного та інноваційного розвитку має наступні структурні елементи: суб'єкт управління, об'єкт управління, цілі управління, критерії управління, елементи об'єкта управління, ресурси управління, методи управління. 


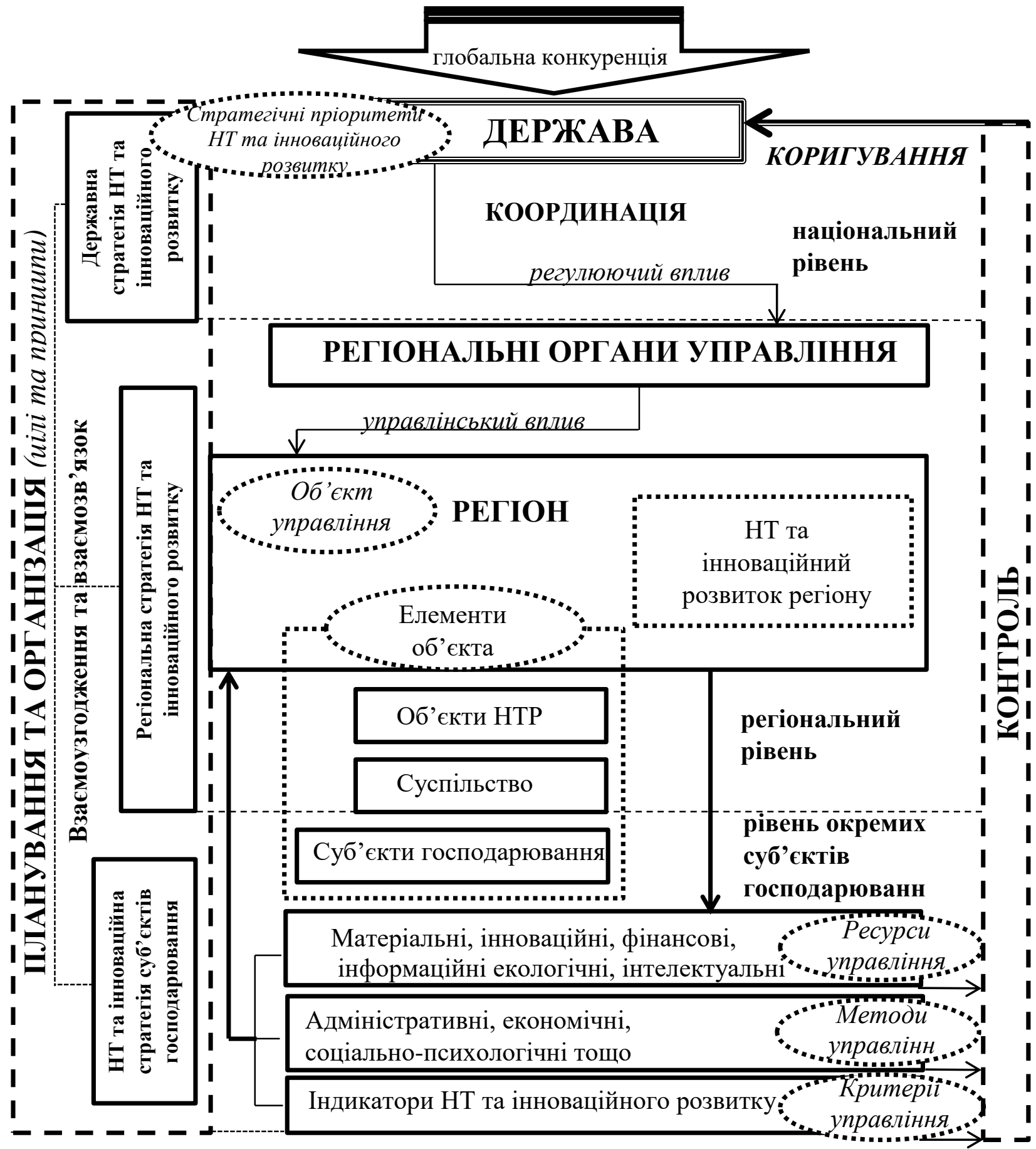

Рис. 1. Еволюція моделей інноваційного розвитку економічних систем та їх внутрішніх взаємозв'язків

Складено автором за [4; 16$]$ 
Суб'єкт управління - це регіональні органи управління, які здійснюють вплив на керовану підсистему, об'єкт управління, за допомогою методів управління. Саме об'єкт управління та мета трансформації його стану i $є$ вихідними елементами при формуванні даного механізму.

Метою здійснення державного управління за допомогою запропонованого механізму $\epsilon$ формування адаптованої до національних умов стратегії науковотехнічного та інноваційного розвитку України 3 урахуванням проблем науковотехнічного розвитку на всіх рівнях господарювання, здійснення ефективної системи управління, планування, прогнозування та коригування при іiі підготовці та реалізації.

У зв'язку із встановленою метою до основних цілей впровадження в практику запропонованого організаційноуправлінського механізму забезпечення науково-технічного та інноваційного розвитку держави слід віднести наступні:

1. Підтримка та ефективне використання інтелектуального потенціалу.

2. Державний нагляд за наданням та розподіленням коштів.

3. Виявлення проблем та перспектив науково-технічного та інноваційного розвитку на регіональному рівні та чітке формування пріоритетних напрямків державного науково-технічного та інноваційного розвитку на всіх рівнях господарювання.

4. Встановлення взаємних зав'язків між всіма рівнями управління.

5. Отримання достовірної інформації від провадження науково-технічної та інноваційної стратегії держави у життя.

Елементами об'єкту управління, на які здійснюється вплив 3 метою досягнення поставлених цілей слід обрати: об'єкти НТР, суспільство, суб'єкти господарювання.

Методи впливу на елементи об'єкта управління, так названі методи управління, представлені в механізмі як інструменти забезпечення науково-технічного та інноваційного розвитку регіону (джерела виникнення: державні, ринкові та соціальні).

До основних задач запропонованого механізму слід віднести наступні:

1. Формування стратегії науковотехнічного та інноваційного розвитку на всіх рівнях управління окремо 3 ціллю планування та організації єдиної державної стратегії науково-технічного та інноваційного розвитку, що матиме взаємоузгоджені елементи, а також тісний взаємозв'язок між ними.

2. Здійснення контролю за формуванням та впровадженням науково-технічної та інноваційної політики на всіх рівнях управління за рахунок державного нагляду за кількістю та якістю використаних ресурсів, відповідністю обраних методів управління, а також чіткого вибору індикаторів науковотехнічного та інноваційного розвитку країни. 3. Проведення постійного коригування на всіх рівнях державного управління за рахунок інформації, що надходить після проведеного контролю 3 ціллю подальшого удосконалення державної науково-технічної та інноваційної політики.

Оцінка державному управлінню надається різними суспільними інститутами: громадянами, сім'ями, трудовими колективами, громадськими об'єднаннями, державними структурами. Суттєва кількість інформації міститься у звітах органів державної влади та органів місцевого самоврядування, а також звітах посадових осіб, громадських обговореннях i голосуваннях (референдумах) 3 різноманітних питань в області державного управління.

Критерії управління слід визначити як кількісний аналог цілей управління. Досягнення мети управляння - основна ціль роботи механізму, тому критеріями управління можна обрати: досягнення цілей управління, ступінь досягнення об'єктом управління бажаного стану. Також до критеріїв управління слід віднести обсяг витрат на управління як фінансових, так i витрат часу. Однак, комплексним критерієм управління $\epsilon$ ефективність, або результативність.

Ефективність управління може бути оцінена шляхом дослідження ступеню досягнення державою встановлення цілей за допомогою конкретного механізму управління. При зміні цілей управління відповідно будуть змінюватися критерії ефективності управління. При оцінці ефективності та результативності державного управління слід, як мінімум, порівняти: цілі, які практично реалізуються в управлінні, 3 цілями, що детерміновані об'єктивними запитами суспільства; цілі, що 
реалізовані в процесах управління, 3 результатами, що отримані за рахунок об'єктивізації державного управління; суспільні потреби і інтереси, суспільні витрати 3 об'єктивними результатами управління; можливості управлінського потенціалу та ступінь їх реального використання.

Ефективність державного управління науково-технічним та інноваційним розвитком доцільно оцінити по результатам реалізації стратегії науково-технічного розвитку держави, що відображені як індикатори розвитку науки, технологій та інновацій в державі.

При виникненні труднощів та суперечностей при формуванні стратегій в рамках наведеного механізму управління, треба повертатися до коригування стратегічних цілей та пріоритетів науковотехнічного та інноваційного розвитку держави.

Для розуміння дій на кожному з рівнів управління визначимо основні повноваження органів всіх рівнів управління (рис. 2).

Запропонований організаційноуправлінський механізм забезпечення науково-технічного та інноваційного розвитку України має п’ять рівнів управління:

1. Верховна Рада та Президент України.

2. Кабінет Міністрів України.

3. Міністерства та відомства, а також інші центральні органи управління.

4. Місцеві органи державної влади та управління.

5. Організації, установи та підприємства, які безпосередньо приймають участь у здійсненні науково-технічної та інноваційної політики.

Для впровадження визначених цілей i задач та досягнення поставленої мети необхідне проведення державою наступних кроків:

1. Створити сприятливі організаційноекономічні та правові умови щодо ефективного використання існуючого науково-технічного потенціалу.

2. Концентрувати ресурси для розвитку та реалізації пріоритетних напрямів науки i техніки.

3. Формувати та реалізовувати довгострокові науково-технічні програми, здійснювати прогнозування індикативних показників інноваційного та науковотехнічного розвитку країни, та проводити постійне коригування напрямів стратегічної діяльності в залежності від фактично отриманих результатів.

4. Розробити дієві механізми інтеграції науки у виробництво.

5. Створити сучасну інфраструктуру науки.

6. Встановити ефективне міжнародне співробітництво у науково-технічній та інноваційній сфері.

У зв'язку 3 посиленням глобалізаційного впливу на країну та виявленням факту, що державний економічний розвиток України на пряму залежить від економічного розвитку регіонів, гостро постає питання координації цілей державної та регіональної політики 3 заходами та пріоритетами галузевих політик.

Обговорення

результатів. Приведення запропонованого організаційноуправлінського механізму забезпечення науково-технічного та інноваційного розвитку України в дію дозволить сформувати ефективну національну науковотехнічну та інноваційну стратегію розвитку, що призведе до повного використання науково-технічного потенціалу країни, економії та більш раціонального використання всіх видів ресурсів.

Цей вид стратегії слід віднести до стратегії опосередкованого (децентралізованого) регулювання, в якій державний вплив на науково-технічну та інноваційну діяльність здійснюється тільки у найважливіших напрямах. Держава займається створенням інноваційної структури, створює науково-технічні інновації за рахунок державного сектору та пропонує їх впровадити економічній сфері, займається виділенням державних ресурсів для створення початкового попиту на нововведення, що призначені для подальшого поширення в економіці країни та стимулюванням суб'єктів різних рівнів господарської діяльності до приймання участі у інноваційних процесах. 


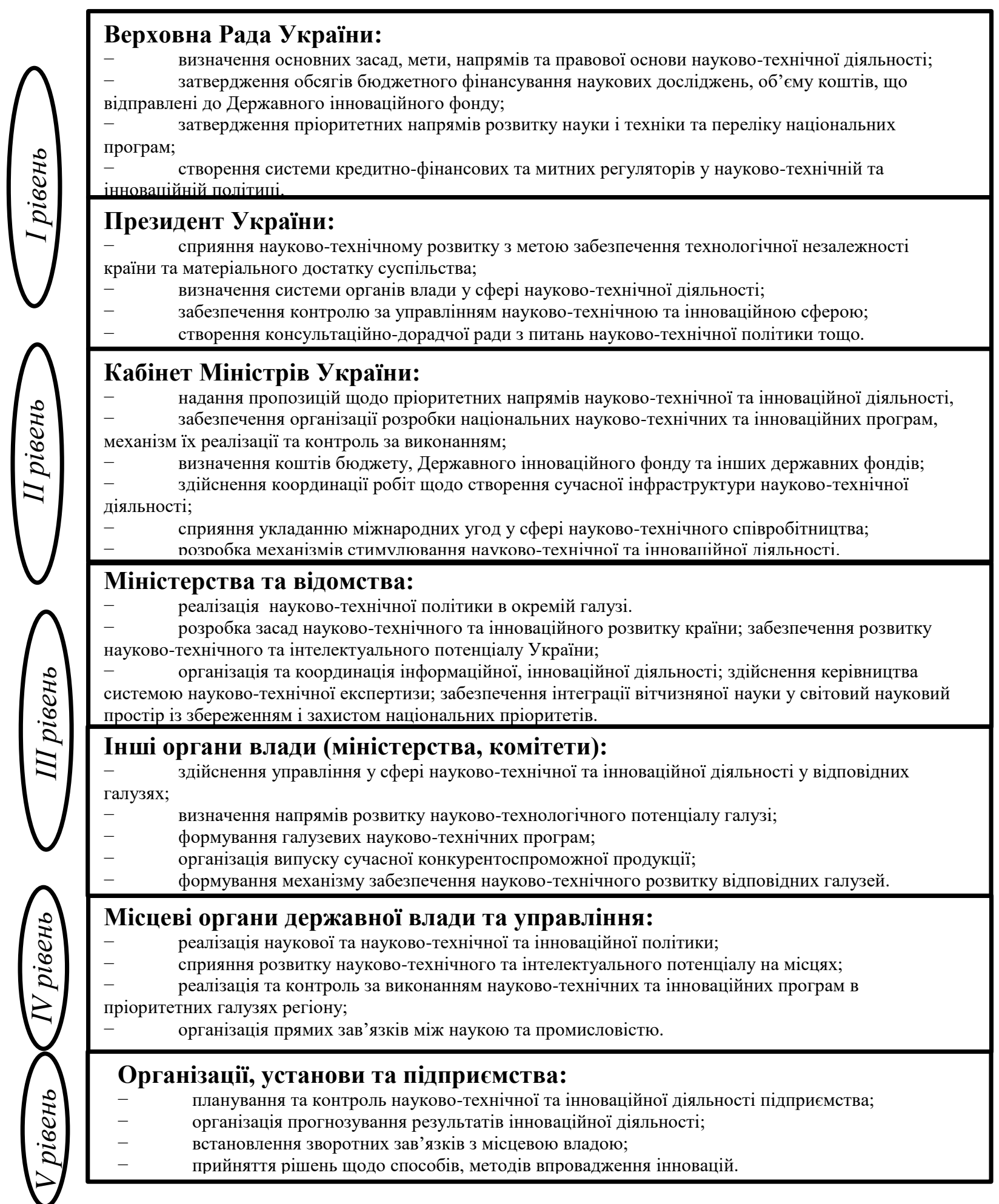

Рис. 2. Повноваження всіх органів управління Джерело: визначено автором 


\begin{abstract}
Висновок. Отже, особливістю запропонованого механізму $\epsilon$ децентралізація державних повноважень на місця під час розробки та впровадження стратегічних програм науково-технічного та інноваційного розвитку за рахунок проведення наступних дій:

-передати відповідні фінансові ресурси на місця;

-удосконалити процеси організації, управління, планування, координації та контролю стратегічної науково-технічної та інноваційної діяльності та виконання поставлених завдань на всіх рівнях;

- запровадити ефективний механізм координації дій центральних та місцевих органів самоврядування та виконавчої влади;

-здійснити постійне коригування напрямів стратегічної науково-технічної та інноваційної діяльності держави в залежності від фактично отриманих результатів дії за індикаторами науково-технічного та інноваційного розвитку країни.
\end{abstract}

\section{Список літератури}

1. Ансофф I. Стратегічне управління: навч. посібник. М.: Економіка. 2006. 358 с.

2. Бегей I. Основні складові сучасних моделей державного управління. Державне управління та місиеве самоврядування. 2015. 2. C. 16-26.

3. Войченко Т. О. Особливості стратегічного управління в Україні. Водний транспорт : Зб. наук. пр. 2(14). К.: КДАВТ. 2012. C.93-96.

4. Воронов О. Інтерпретація поняття «управлінське рішення» у сфері державного управління. Державне управління та місиеве самоврядування. 2015. 2. С. 38-47.

5. Дроб О. М. Школи стратегії як основа розробки сталої парадигми стратегічного управління. Вісник Національного університету «Львівська політехніка». Проблеми економіки та управління. 2013. 754. C. $148-158$.

6. Єфіменкова Н. Моделювання системи державного управління інвестиційноінноваційними процесами в Україні. Державне управління та місчеве самоврядування. 2014. 2. C. 48-61.

7. Катькало В. С. Эволюция теории стратегического управления: автореф. дис. ... д-ра экон. наук: 08.00.05.Спб. 2007. 45 с.
Перспективою подальших досліджень є розробка державної стратегії науковотехнічного та інноваційного розвитку після надання сформованих та обгрунтованих регіональних та галузевих стратегій науковотехнічного та інноваційного розвитку на основі стратегій відповідних суб'єктів господарювання.

Слід зазначити, що такий вид стратегії відноситься до стратегії децентралізованого регулювання, що на перший план в науковотехнічній та інноваційній діяльності виводить окремі суб'єкти господарювання, створює сприятливі правові, економічні та інші умови, на відміну від існуючої стратегії активного втручання, що полягає у відігріванні провідної ролі державою при виборі пріоритетів науково-технічного розвитку.

8. Козловський С. В. Стратегічне управління розвитком регіональних економічних систем. Ефективна економіка. 2010. URL: http://www.economy.nayka.com.ua/?op=1\&z=33 4 (дата звернення: 03.11.2019).

9. Кун Т. Структура наукових революцій. K.: Port-Royal. 2001. 228 c.

10. Мазур А. Г. Управління в регіональних економічних системах: теорія, методологія. Вінниця: Консоль. 2003. 408 с.

11. Минцберг Г. Школы стратегий. Стратегические сафари: экскурсия по дебрям стратегий менеджмента. Спб.: Питер. 2001. 336 c.

12. Орлова Н. С., Іващенко А. I. Стратегічне управління розвитком економіки України. Економіка та держава. 2009. 6. С.1820.

13. Середа О В. Стратегічне управління розвитком міст: дис. канд.: 08.00.05 Луцьк. 2013. $266 \mathrm{c}$.

14. O'Shannasy, T. Lessons from the Evolution of Strategy Paradigm. Working Paper Series. 1999. №20. P. 1-25.

15. Schendel, D. and Hofer, C. (1979), Strategic Management: A New View of Business Policy and Planning, Little Brown, Boston, P. 198.

16. Wilson I. Strategic planning for the millennium: Resolving the dilemma, Long Range Planning. 1998. Vol. 31. №4. PP. 507-513. 


\section{References}

1. Ansoff I. Strategicheskoe upravlenie / I.Ansoff ; sokr. per. s angl.; nauch. red. i avt. predisl. L.I. Evenko. M.: Ekonomika. 1989. 519 p. [in Russian].

2. Begej I. Osnovni skladovi suchasny`x modelej derzhavnogo upravlinnya. Derzhavne upravlinnya ta misceve samovryaduvannya. 2015. 2. P. $16-26$ [in Ukr].

3. Vojchenko T. O. Osobly`vosti strategichnogo upravlinnya $\mathrm{v}$ Ukrayini. Vodny`j transport : Z Zb. nauk. pr. 2(14). K.: KDAVT. 2012. P. 93-96 [in $\mathrm{Ukr}]$.

4. Voronov O. Interpretaciya ponyattya «upravlins'ke rishennya» u sferi derzhavnogo upravlinnya. Derzhavne upravlinnya ta misceve samovryaduvannya. 2015. 2. P. 38-47 [in Ukr].

5. Drob O. M. Shkoly` strategiyi yak osnova rozrobky` staloyi parady`gmy` strategichnogo upravlinnya. Visny`k Nacional'nogo universy`tetu «L`vivs`ka politexnika». Problemy` ekonomiky` ta upravlinnya. 2013. 754. P. 148-158 [in Ukr].

6. Yefimenkova N. Modelyuvannya sy`stemy` derzhavnogo upravlinnya investy`cijnoinnovacijny`my procesamy` v Ukrayini. Derzhavne upravlinnya ta misceve samovryaduvannya. 2014. 2. P. 48-61 [in Ukr].

7. Kat'kalo V. S. Эvolyucy`ya teory`y' strategy 'cheskogo upravleny`ya: avtoref. dy`s. ... d-ra эkon. nauk: 08.00.05. Spb. 2007. 45 p. [in $\mathrm{Ukr]}$.

8. Kozlovs`ky`j S. V. Strategichne upravlinnya rozvy`tkom regional’ny`x ekonomichny`x sy`stem. Efekty`vna ekonomika. 2010. [online]. Retrieved from: $\mathrm{http} / / / \mathrm{www} \cdot$ economy.nayka.com.ua/?op=1\&z=33 4 [in Ukr].

9. Kun T. Struktura naukovy`x revolyucij. K.: Port-Royal. 2001. 228 p. [in Ukr].

10. Mazur A. G. Upravlinnya v regional`ny`x ekonomichny`x sy`stemax: teoriya, metodologiya. Vinny`cya: Konsol`. 2003. 408 p. [in $\mathrm{Ukr}$ ].

11. My’nczberg G. Shkolb strategy`j. Strategy'chesky'e safary': эkskursy'ya po debryam strategy`j menedzhmenta. Spb.: Py`ter. 2001. 336 p. [in Russian].

12. Orlova N. S., Ivashhenko A. I. Strategichne upravlinnya rozvy 'tkom ekonomiky' Ukrayiny'. Ekonomika ta derzhava. 2009. 6. P.1820 [in Ukr].

13. Sereda O V. Strategichne upravlinnya rozvy`tkom mist: dy`s. kand.: 08.00.05 Lucz`k. 2013. 266 p. [in Ukr].

14. O'Shannasy, T. Lessons from the Evolution of Strategy Paradigm. Working Paper Series. 1999. №20. P. 1-25.

15. Schendel, D. and Hofer, C. (1979), Strategic Management: A New View of Business Policy and Planning, Little Brown, Boston, P. 198.

16. Wilson I. Strategic planning for the millennium: Resolving the dilemma, Long Range Planning. 1998. Vol. 31. №4. PP. 507-513.

Надійшла до редакиї 30.11.2019p.

Шакіна Наталія Анатоліївна - к.е.н., доцент кафедри управління і фінансово-економічної безпеки ДВНЗ «Донецький національний технічний університет»

E-mail: nataliia.shakina@ donntu.edu.ua

\section{ORGANIZATIONAL AND MANAGEMENT MECHANISM FORMATION OF SUPPORT OF SCIENTIFIC-TECHNICAL AND INNOVATIVE DEVELOPMENT OF UKRAINE ON THE BASIS OF FUNCTIONAL APPROACH}

The article proposes an organizational and management mechanism for ensuring scientific, technical and innovative development of Ukraine through the principles of innovative management. In the proposed mechanism, the following structural elements are distinguished: the subject of management, the control object, management objectives, management criteria, elements of the control object, management resources, and management methods. With the help of the proposed mechanism, the goal of government management is defined, which is the formation of a strategy of scientific, technical and innovative development of Ukraine adapted to the national conditions, taking into account the problems of scientific and technological development at the levels of economy, the implementation of an effective management system, planning, forecasting and correction in its preparation and implementation.

According to the established goal, the main tasks of the mechanism are distinguished. Determined, that the effectiveness of management can be assessed by examining the extent to which the government achieves the goal 
setting through a specific management mechanism. When the management objectives change, the management effectiveness criteria will change accordingly. If difficulties and contradictions arise during the formation of strategies within the framework of the described management mechanism, it is necessary to return to the adjustment of strategic goals and priorities of scientific, technical and innovative development of the country.

A feature of the proposed mechanism is: decentralization of government powers to the places during the working out and implementation of strategic programs of scientific, technical and innovative development through the following actions: transfer relevant financial resources to the local management; to improve the processes of organization, management, planning, coordination and control of strategic scientific, technical and innovation activities, and realization of tasks at all levels; to introduce an effective mechanism for coordinating the actions of central and local government and executive authorities; to carry out constant updating of directions of strategic scientific, technical and innovative activity of the country depending on actually received results of action on indicators of scientific, technical and innovative development of the country.

Keywords: strategic management; scientific, technical and innovative development; national management mechanism; multi-level management system

Shakina Nataliia - PhD in Economics, Docent of Department management and financial

and economic security

State Higher Educational Institution «Donetsk National Technical University»

E-mail: nataliia.shakina@donntu.edu.ua

\section{ФОРМИРОВАНИЕ ОРГАНИЗАЦИОННО-УПРАВЛЕНЧЕСКОГО МЕХАНИЗМА ОБЕСПЕЧЕНИЯ НАУЧНО-ТЕХНИЧЕСКОГО И ИННОВАЦИОННОГО РАЗВИТИЯ УКРАИНЫ НА ОСНОВЕ ФУНКЦИОНАЛЬНОГО ПОДХОДА}

В статье предложен организационно-управленческий механизм обеспечения научно-технического и инновационного развития Украины, который сформирован на принциипах инновационного управления. В предложенном механизме выделено следующие структурные элементы: субъект управления, объект управления, цели управления, критерии управления, элементы объекта управления, ресурсы управления, методы управления. C помощью предложенного механизма определена иель осуществления государственного управления, которой является формирование адаптированной к национальным условиям стратегии научно-технического и инновационного развития Украины с учетом проблем научнотехнического развития на всех уровнях хозяйствования, осуществления эфрективной системы управления, планирования, прогнозирования и корректировки при ее подготовке и реализации. Согласно установленной иели выделены основные задачи механизма.

Установлено, что эффективность управления может быть оценена путем исследования степени достижения государством установления целей с помощью конкретного механизма управления. При изменении целей управления соответственно будут меняться критерии эффективности управления. При возникновении трудностей и противоречий во время формирования стратегий в рамках описанного механизма управления необходимо возвращаться к корректировке стратегических целей и приоритетов научно-технического и инновационного развития государства.

Особенностью предложенного механизма является: децентрализация государственных полномочий на места во время разработки и внедрения стратегических программ научно-технического и инновационного развития за счет проведения следующих действий: передать соответствующие финансовые ресурсы на места; усовершенствовать процессы организации, управления, планирования, координации и контроля стратегической научно-технической и инновационной деятельности, и выполнения поставленных задач на всех уровнях; ввести эффективный механизм координации действий центральных и местных органов самоуправления и исполнительной власти; осуществлять постоянную корректировку направлений стратегической научно-технической и инновачионной деятельности государства в зависимости от фактически полученных результатов действия по индикаторам научнотехнического и инновационного развития страны.

Ключевые слова: стратегическое управление; научно-техническое и инновачионное развитие; национальный механизм управления; многоуровневая система управления

Шакина Наталья Анатольевна - к.э.н., доцент кафедры управления и

финансово-экономической безопасности

ГВУЗ «Донецкий национальный технический университет»

E-mail: nataliia.shakina@donntu.edu.ua 